\title{
Two new marine ciliates, Euplotes sinicus sp. nov. and Euplotes parabalteatus sp. nov., and a new small subunit rRNA gene sequence of Euplotes rariseta (Ciliophora, Spirotrichea, Euplotida)
}

\author{
Jiamei Jiang, ${ }^{1}$ Oianqian Zhang, ${ }^{1}$ Xiaozhong $\mathrm{Hu},{ }^{1}$ Chen Shao, ${ }^{1}$ \\ Khaled A. S. Al-Rasheid ${ }^{2}$ and Weibo Song ${ }^{1}$ \\ ${ }^{1}$ Laboratory of Protozoology, Ocean University of China (OUC), Qingdao 266003, PR China \\ ${ }^{2}$ Zoology Department, King Saud University, Riyadh 11451, Saudi Arabia
}

Correspondence
Xiaozhong Hu
xiaozhonghu@ouc.edu.cn

\section{INTRODUCTION}

Among ciliates, the genus Euplotes Ehrenberg, 1830 apparently has no counterpart with regard to the variety of species, worldwide distribution and adaptive plasticity. Tuffrau (1954), Borror (1972) and Carter (1972) revised the genus considering the pattern of the silverline system as an important character for species classification. In the last three decades, about 30 new morphospecies of Euplotes have been reported in addition to the 51 species classified by Curds (1975) in his guide to Euplotes taxonomy.

In more recent studies on ciliate fauna in northern China seas, several species of Euplotes have been identified and redescribed (Song \& Packroff, 1997; Song \& Wilbert, 1997; Jiang et al., 2008). The present paper describes two novel species based on their morphology, diagnostic characters, small subunit rRNA (SSU rRNA) gene sequence homology and phylogenetic relationship with their congeners.

\footnotetext{
Abbreviations: BI, Bayesian inference; $\mathrm{ML}$, maximum-likelihood; MP, maximum-parsimony; SSU rRNA, small subunit rRNA.

The GenBank/EMBL/DDBJ accession number for the small subunit rRNA gene sequence of Euplotes rariseta is FJ423449.
}

\section{METHODS}

Euplotes sinicus sp. nov. and Euplotes parabalteatus sp. nov. were collected in September 2007 from seawater off Qingdao (Tsingtao, $\left.120^{\circ} 18^{\prime} \mathrm{E} ; 36^{\circ} 04^{\prime} \mathrm{N}\right)$, China. Glass slides were used as artificial substrates to collect ciliates. Briefly, the slides were carefully taken out after being exposed to the seawater for about 7-10 days, and transferred to Petri dishes with seawater from the sampling site. Isolated specimens were maintained in the laboratory for observation and further studies ( $\mathrm{Hu}, 2008)$.

The specimens were examined in vivo at different magnifications before silver impregnation. Live observations were carried out using an oil immersion objective with bright-field and Nomarski differential interference contrast optics (Song et al., 2009). The infraciliature was impregnated by using the protocol of Wilbert (1975). The Chatton-Lwoff method was used for revealing the silverline systems (Wilbert \& Song, 2008). Counts and measurements on stained specimens were performed at a magnification of $\times 1000$ with a $\times 1.25$ optovar device. Drawings were made with the help of a camera lucida. Terminology is mainly according to Curds $(1975,1977)$ and Berger (2006).

The SSU rRNA gene from one population of E. rariseta isolated from Qingdao, China, was sequenced. Genomic DNA extraction, PCR amplification and sequencing of the SSU rRNA gene were performed according to Yi et al. (2008a). Two primers were used: 18S-F (5'AACCTGGTTGATCCTGCCAGT- $3^{\prime}$ ) and 18S-R (5'-TGATCCTTCTGCAGGTTCACCTAC- $3^{\prime}$ ). Sequences of the SSU rRNA gene of $E$. sinicus and E. parabalteatus were obtained from the GenBank database (accession numbers FJ346568 and FJ423448, respectively); these were published recently as unidentified (Yi et al., 2009). The other 
Table 1. SSU rRNA sequences from the GenBank database used in this study

\begin{tabular}{|llll|}
\hline Species & Accession no. & \multicolumn{1}{c|}{ Species } & Accession no. \\
\hline Amphisiella annulata & DQ832260 & Euplotes patella & EF094964 \\
Aspidisca steini & AF305625 & Euplotes plicatum & EF094966 \\
Aspidisca aculeata & EF123704 & Euplotes raikovi & EF094973 \\
Certesia quadrinucleata & DQ059581 & Euplotes rariseta & AJ305248 \\
Diophrys appendiculata & AY004773 & Euplotes rariseta QD-2 & FJ423449 \\
Diophrys oligothrix & DQ353850 & Euplotes sinicus & FJ423448 \\
Diophrys scutum & DQ353851 & Euplotes sp. & AF492706 \\
Diophrysopsis hystrix & EF486861 & Euplotes trisulcatus & EF690810 \\
Euplotes aediculatus & M14590 & Euplotes vannus & AY004772 \\
Euplotes bisulcatus & EF094965 & Euplotes woodruffi & AF492707 \\
Euplotes charon & AF492705 & Euplotidium arenarium & Y19166 \\
Euplotes crassus & AY361895 & Gastrocirrhus monilifer & DQ864734 \\
Euplotes daidaleos & EF690811 & Laboea strobila & AF399151 \\
Euplotes elegans & DQ309868 & Loxodes striatus & U24248 \\
Euplotes encysticus & EF535728 & Onychodromopsis flexilis & AY498652 \\
Euplotes euryhalinus & EF094968 & Phacodinium metchnikoffi & AJ277877 \\
Euplotes eurystomus & AJ310491 & Prodiscocephalus borrori & DQ646880 \\
Euplotes focardii & EF094960 & Protocruzia adherens & AY217727 \\
Euplotes harpa & AJ305252 & Protocruzia contrax & DQ190467 \\
Euplotes magnicirratus & AJ549210 & Paradiophrys irmgard & EU189070 \\
Euplotes minuta & AY361900 & Paradiophrys sp. & EU189071 \\
Euplotes muscicola & AJ305254 & Strombidium apolatum & DQ662848 \\
Euplotes nobilii & EF094970 & Strombidinopsis jeokjo & AJ628250 \\
Euplotes octocarinatus & EF094963 & Tintinnidium mucicola & AY143563 \\
Euplotes parabalteatus & FJ346568 & Uronychia binucleata & EF198667 \\
Euplotes parawoodruffi & AF452708 & Uronychia setigera & EF198669 \\
Euplotes parkei & AJ305247 & Uronychia transfuga & AF260120 \\
& & & \\
\hline
\end{tabular}

nucleotide sequences used in this study are all available in the GenBank database (Table 1).

The structural similarities among sequences of E. sinicus, $E$. rariseta and Euplotes raikovi were calculated pairwise as described by Elwood et al. (1985). Phylogenetic trees based on the SSU rRNA gene sequences for the family Euplotidae were constructed using three different methods: Bayesian inference (BI), maximum-likelihood (ML) and maximum-parsimony (MP). Loxodes striatus (U24248) was selected as the out-group species. Phylogenetic analyses were performed according to Yi et al. (2008b).

The topologies of the BI, ML and MP trees were almost identical. Therefore, they were merged into a single tree for purposes of illustration. This tree was formatted by using MEGA (Kumar et al., 2004) and exported from the program as a graphics file for construction of the final tree.

\section{RESULTS AND DISCUSSION}

\section{Euplotes sinicus sp. nov.}

Diagnosis. Marine Euplotes with conspicuous dorsal ridges, $60-95 \times 35-65 \mu \mathrm{m}$ in vivo. Buccal field about twothirds of cell length with about 41 membranelles; always 10 frontoventral, 5 transverse, 2 caudal and single fine marginal cirri; 7 dorsal kineties with about 12 dikinetids in mid-dorsal row. Macronucleus curved-bar- or Cshaped. Dorsal silverline system double-patella-I type. Morphometric data are summarized in Table 2.

Type location. Isolated from Qingdao, China, on 17 September 2007. Salinity about $27 \%$ and water temperature about $23{ }^{\circ} \mathrm{C}$.

Type specimens. One holo- and one paratype slide with protargol- and silver nitrate-impregnated specimens, respectively, have been deposited in the Natural History Museum, London, UK $(2008: 8: 4: 1$ and 2008:8:4:2, respectively), and another set of paratype slides have been deposited in the Laboratory of Protozoology, Ocean University of China (OUC), Qingdao, PR China (JJM2007091703-1 and JJM2007091703-2).

Etymology. The species name sinicus (Latin adjective, Chinese) refers to the fact that this species was first discovered in China.

Description. Cells in vivo usually $70-80 \mu \mathrm{m}$ long, generally oval in outline as shown in Figs $1(\mathrm{a}-\mathrm{c})$ and $2(\mathrm{a}, \mathrm{c}, \mathrm{d})$. Left and right margins usually less convex in slim individuals (Figs 1c, 2d) than those in well-fed cells (Figs 1b, 2c); 
Table 2. Morphometric data for $E$. sinicus sp. nov. (upper rows) and E. parabalteatus sp. nov. (lower rows)

Data are based on protargol-impregnated specimens. CV, coefficient of variation $(\%)$.

\begin{tabular}{|lrrrrrr|}
\hline Characteristic & Min & Max & Mean & SD & CV & $\boldsymbol{n}$ \\
\hline Cell length $(\mu \mathrm{m})$ & 65 & 92 & 77.5 & 7.29 & 9.4 & 16 \\
& 35 & 44 & 38.3 & 2.78 & 7.3 & 13 \\
Cell width $(\mu \mathrm{m})$ & 37 & 62 & 48.0 & 7.18 & 15.0 & 16 \\
& 26 & 36 & 26.7 & 1.70 & 9.5 & 13 \\
Adoral membranelles & 38 & 46 & 40.9 & 5.38 & 10.3 & 16 \\
Frontoventral cirri & 19 & 23 & 20.4 & 1.39 & 6.8 & 13 \\
Transverse cirri & 10 & 10 & 10 & 0 & 0 & 16 \\
& 10 & 10 & 10 & 0 & 0 & 13 \\
Marginal cirrus & 5 & 5 & 5 & 0 & 0 & 25 \\
& 5 & 5 & 5 & 0 & 0 & 25 \\
Caudal cirri & 1 & 1 & 1 & 0 & 0 & 25 \\
& 2 & 2 & 2 & 0 & 0 & 25 \\
Dorsal kineties & 2 & 2 & 2 & 0 & 0 & 25 \\
& 2 & 2 & 2 & 0 & 0 & 25 \\
Dikinetids in mid-dorsal & 7 & 7 & 7 & 0 & 0 & 16 \\
kinety & 6 & 7 & 6.1 & 0.28 & 4.6 & 13 \\
Dikinetids in leftmost & 8 & 16 & 12.0 & 1.37 & 11.4 & 16 \\
dorsal kinety & 3 & 4 & 4.1 & 0.50 & 12.1 & 16 \\
& 2 & 3 & 2.3 & 0.48 & 20.1 & 13 \\
& & & & & &
\end{tabular}

anterior end narrowly rounded with a distinct projection at right side (Fig. 1a, g), while posterior end widely rounded. Cell body dorsoventrally flattened about $2: 1$ with ventral side somewhat convex and dorsal side strongly arched (Fig. 2b). Buccal field approximately two-thirds of cell length. On ventral side, 3 conspicuous ridges extending posteriorly to transverse cirri (Figs 1a, 2e); on dorsal side about 5 dominant dorsal ridges almost extending over the entire cell length (Fig. 1d; Figs 1f, 2b, f, arrows). Dorsal cilia conspicuous, about $5 \mu \mathrm{m}$ long (Fig. $2 \mathrm{~g}$ ).

Numerous granules (possibly mitochondria) (Fig. 2h, arrows) about $2 \mu \mathrm{m}$ across, extremely densely packed beneath pellicle (Fig. 1h). Cytoplasm colourless, highly transparent at marginal area, but opaque in central part where several to many different-sized lipid droplets and a few food vacuoles are included. Contractile vacuole adjacent to the rightmost transverse cirrus (Fig. 1a). Macronucleus variable in shape: from typical C-shaped (mostly) to slightly curved (Fig. 1e).

Locomotion typically by moderately fast crawling or slight jerking.

Infraciliature as shown in Figs $1(\mathrm{~g}, \mathrm{i}, \mathrm{j})$ and $2(\mathrm{j}, \mathrm{k})$. Paroral membrane small, typically composed of many irregularly arranged kinetosomes; positioned below the buccal lip (Fig. 1g). Adoral zone prominent, composed of 38-46 membranelles. Consistently 10 frontoventral cirri arranged in normal pattern, 5 strong transverse cirri and 2 caudal cirri. Single fine marginal cirrus located on left side of the cell posterior to buccal field. Always 7 dorsal kineties almost extending over entire length of the cell except the leftmost one which includes about 4 dikinetids; middle row with about 11-16 dikinetids (Fig. 1j). Silverline system on dorsal side double-patella-I type (Fig. 1j).

Comparison and discussion. Hitherto, only five morphotypes possessing the single marginal cirrus and a double-patella silverline pattern have been reported: Euplotes algivora, Euplotes zenkewitchi, Euplotes raikovi, Euplotes rariseta and Euplotes strekovi. Hence, we only compared these species with E. sinicus.

Among these species, E. algivora is very similar to $E$. sinicus in terms of its infraciliature (Agatha et al., 1990; Fig. 3a-c, Table 3). However, E. algivora can be separated from $E$. sinicus by its slender cell shape (vs oval to broadly oval), conspicuous long and strong marginal cirrus (vs short and fine marginal cirrus), and 2 (vs 5) dorsal ridges.

E. zenkewitchi can be clearly distinguished from E. sinicus by the number of frontoventral cirri (9 vs 10) and dorsal kineties ( $8-10$ vs 7 ), as well as the double-patella-II type of dorsal silverline system (vs double-patella-I) (Burkovsky, 1970; Fig. 3d, e, Table 3).

Both E. strekovi and E. raikovi resemble E. sinicus in cell size and shape; however, E. strekovi and E. raikovi possess one reduced cirrus (absent in E. sinicus), fewer frontoventral cirri (9 and 8, respectively, vs 10), and thus cannot be confused with E. sinicus. Additionally, E. strekovi has the double-patella-II type of dorsal silverline system (vs double-patella-I type) and 6 (vs 5) transverse cirri (Agamaliev, 1967; Jiang et al., 2008; Fig. 3f-i, Table 3).

E. rariseta differs from E. sinicus in cell size $(30-50 \times 20-$ 40 vs $65-92 \times 37-62 \mu \mathrm{m})$, number of membranelles (1722 vs 38-46) and number of dikinetids in the middle dorsal kinety (5-7 vs 11-16) (Ma et al., 2007; Fig. 3j-m, Table 3).

SSU rRNA gene sequence analysis. The SSU rRNA gene sequence of E. sinicus is $1.72 \mathrm{~kb}$ in length and has a GC content of $45.0 \mathrm{~mol} \%$. The dissimilarity between $E$. sinicus, E. rariseta and E. raikovi is supported by pairwise comparison of their sequences. Sequences of E. sinicus and E. rariseta differ in 256 nucleotides and exhibit $89.2 \%$ similarity, whereas E. sinicus differs in 309 nucleotides from E. raikovi with a similarity of only $86.7 \%$

\section{Euplotes parabalteatus sp. nov.}

Diagnosis. Small-sized marine Euplotes, about $35 \mu \mathrm{m}$ long in vivo, slender oval; no conspicuous dorsal or ventral ridges. Buccal field over two-thirds of cell length with about 20 membranelles; consistently 10 frontoventral cirri, 2 marginal cirri positioned posterior to 5 relatively fine transverse cirri and close to 2 caudal cirri; 6-7 dorsal kineties with about 9 dikinetids in mid-dorsal row. Macronucleus slightly curved-bar-shaped. Dorsal silver- 


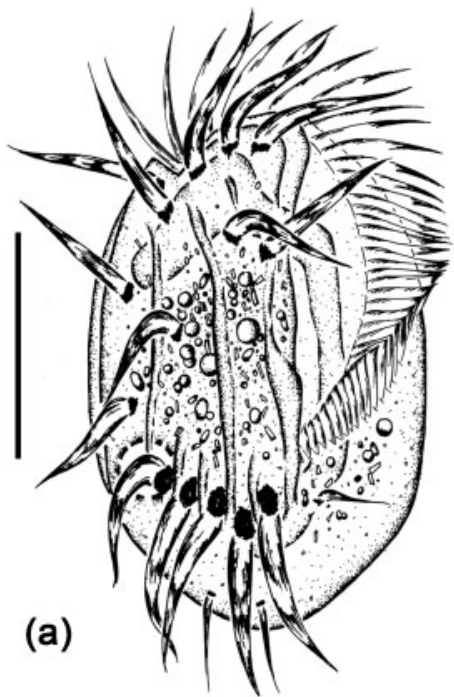

(b)
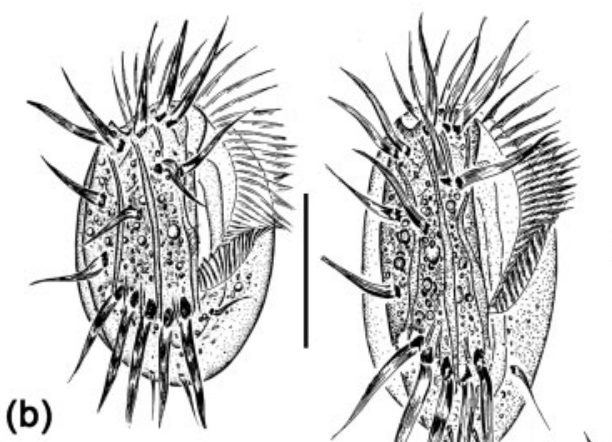

(c)
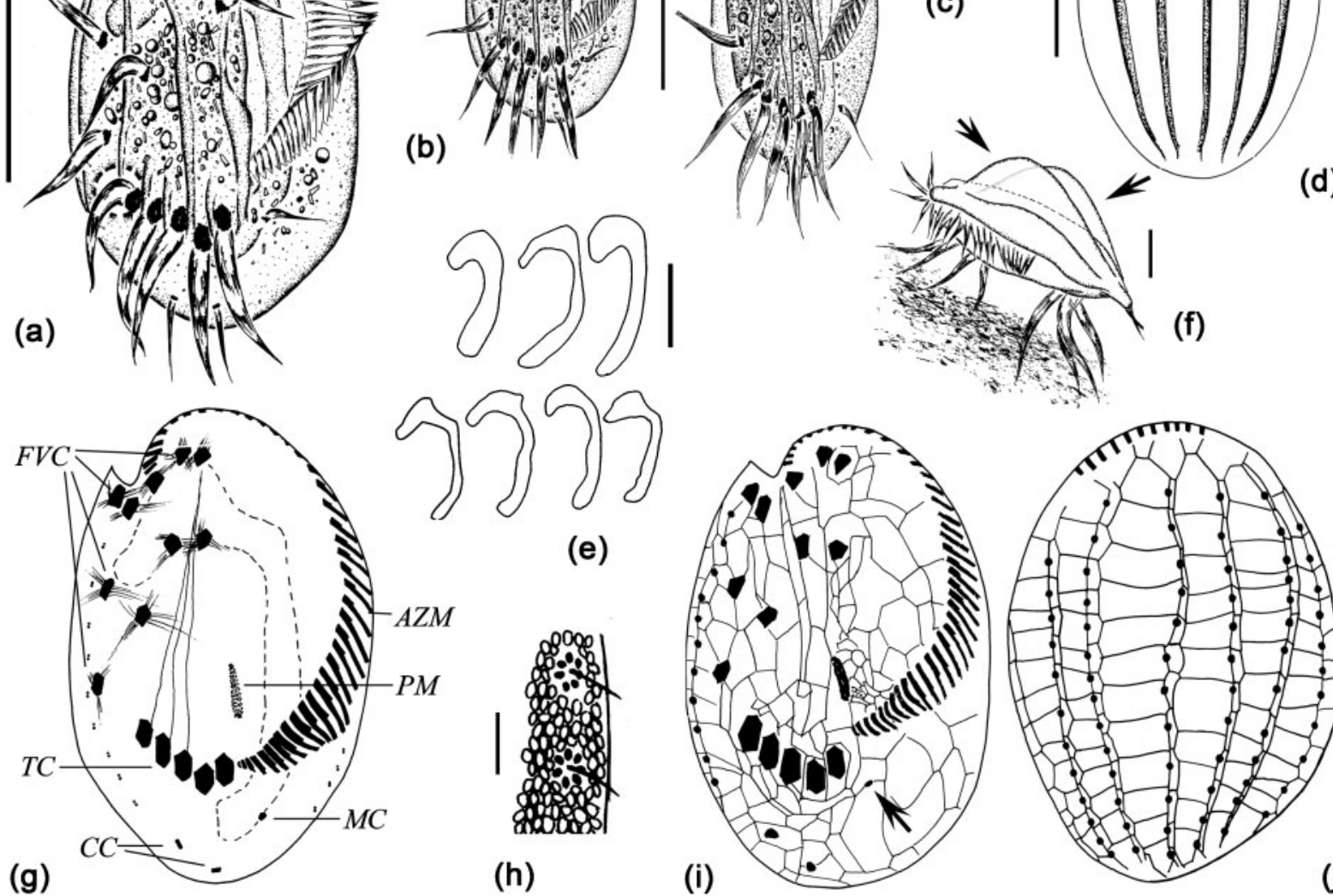

(e)

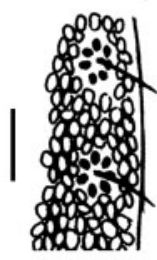

(h)
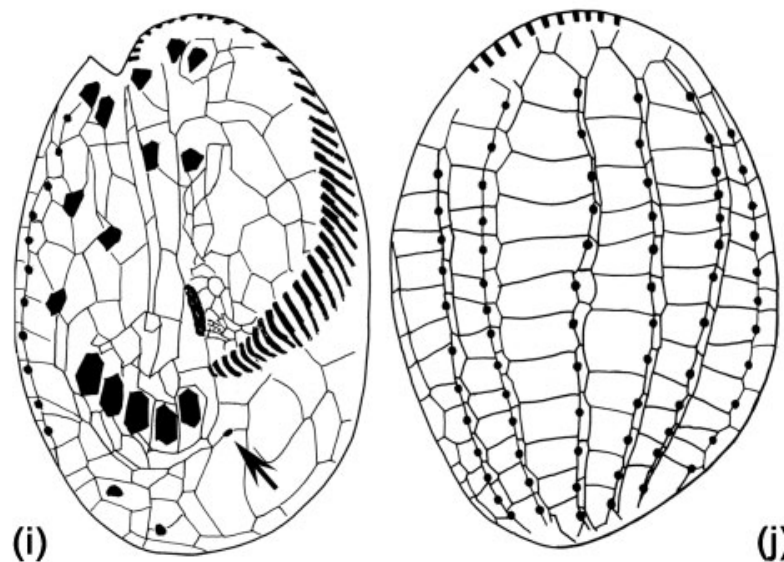

(j)

Fig. 1. E. sinicus sp. nov. in vivo $(a-d, f, h)$, and after protargol $(e, g)$ and silver nitrate $(i, j)$ impregnation. (a-c) Ventral view of different individuals. (d) Dorsal view, showing ridges. (e) Different shapes of macronucleus. ( $f$ ) Lateral view, showing conspicuous ridges (arrows). (g) Ventral view, showing infraciliature. (h) Portion of dorsal view, showing the granules beneath the pellicle. (i, j) Silverline system on ventral and dorsal sides; note the single fine marginal cirrus (arrow). AZM, adoral zone of membranelles; CC, caudal cirri; FVC, frontoventral cirri; MC, marginal cirrus; PM, paroral membrane; TC, transverse cirri. Bars, $30 \mu \mathrm{m}$ [a (also applies to $\mathrm{g}$, $\mathrm{i}$ and j) and $\mathrm{d}-\mathrm{f}$ ], $40 \mu \mathrm{m}$ (b and c) and $10 \mu \mathrm{m}(\mathrm{h})$.

line system double-eurystomus type. Morphometric data are summarized in Table 2.

Type location. Occurred in Qingdao, China, on 17 September 2007. Salinity about $27 \%$ and water temperature about $23{ }^{\circ} \mathrm{C}$.

Type specimens. One holo- and one paratype slide with protargol- and silver nitrate-impregnated specimens, respectively, have been deposited in the Laboratory of Protozoology, Ocean University of China (OUC), Qingdao, PR China (JJM2007091701-1 and JJM2007091701-2, respectively), and another paratype slide with protargolimpregnated specimens has been deposited in the Natural History Museum, London, UK $(2008: 8: 5: 1)$.
Etymology. The species name parabalteatus is a composite of the prefix para- (Greek preposition, beside, like) and the species name balteatus, and refers to the similarity of this species to Euplotes balteatus.

Description. Cells in vivo about $30-35 \mu \mathrm{m}$ long; cell body shape stable, generally elongate oval as shown in Figs $4(\mathrm{a}, \mathrm{b})$ and $5(\mathrm{a}-\mathrm{c})$; some specimens possibly broadly oval in outline prior to division; dorsoventrally highly flattened with dorsal side little arched, ventral side concave (Fig. 4c). Adoral zone prominent, about two-thirds to three-quarters of cell length (Fig. 4a), and composed of 1923 adoral membranelles.

One short evident ridge on ventral side located between transverse cirri (Fig. 5e, arrow). On dorsal surface neither 

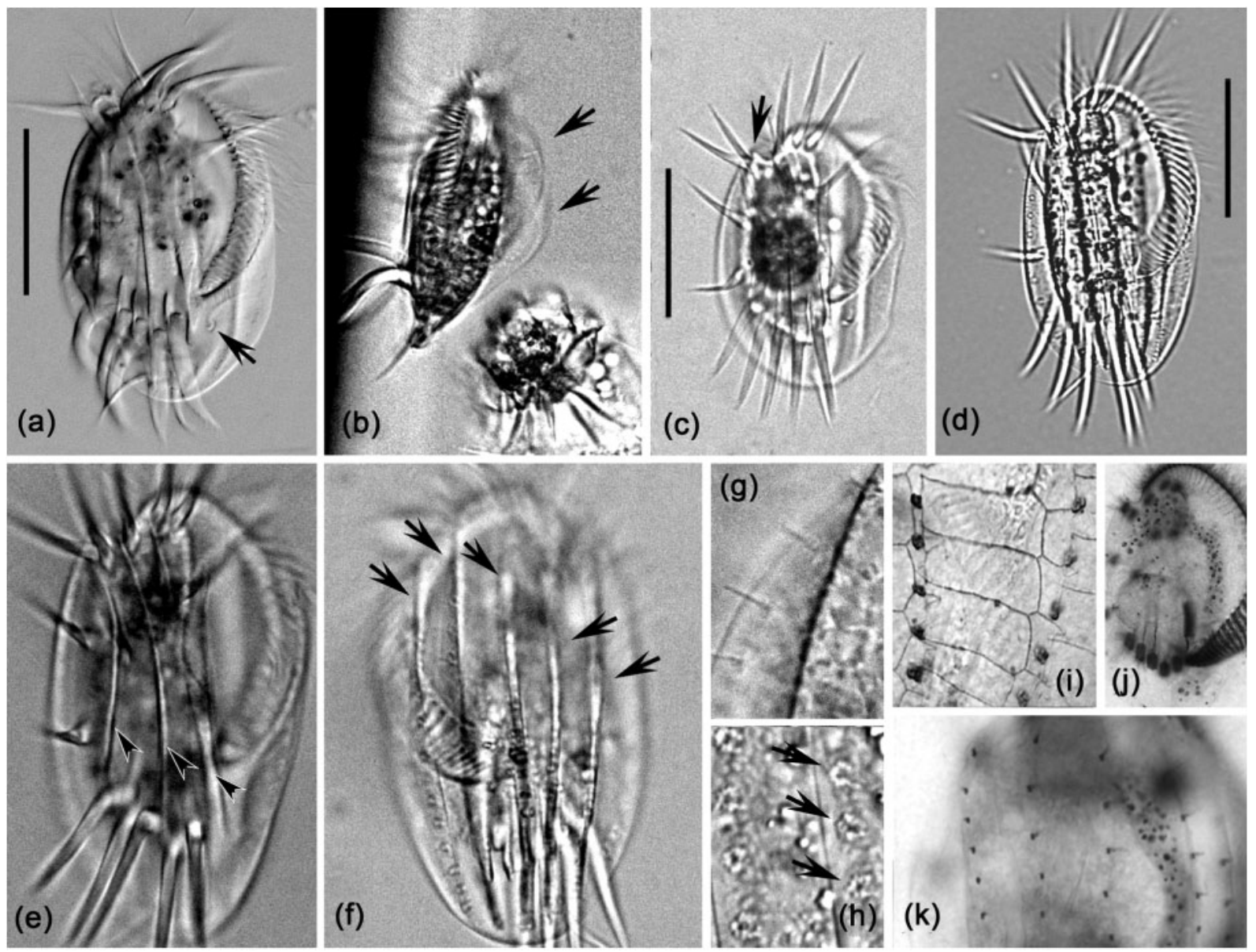

Fig. 2. Photomicrographs of E. sinicus sp. nov. in vivo (a-h), and after silver nitrate (i) and protargol (j, $\mathrm{k}$ ) impregnation. (a) Ventral view of a representative specimen. Arrow shows the fine marginal cirrus. (b) Lateral and underside views; arrows point to the dominant dorsal ridges. (c, d) Ventral views of other individuals. Arrow in (c) shows the projection on anterior right of the cell body. (e) Ventral view, showing three long ridges on ventral side (arrowheads). (f) Dorsal view, showing the dorsal ridges (arrows). (g) Detailed view, showing the dorsal cilia. (h) Detailed view; arrows point to the granules around the dorsal cilia. (i) Portion of dorsal silverline system. (j) Ventral view, showing the typical shape of macronucleus. (k) Portion of dorsal view, showing the arrangement of the dorsal kineties. Bars, $40 \mu \mathrm{m}(\mathrm{a}, \mathrm{c}, \mathrm{d})$.

ridges nor grooves detectable (Fig. 5f). Ellipsoidal granules (about $1.5 \times 0.8 \mu \mathrm{m}$ ) packed together around the dorsal cilia beneath pellicle in a flower pattern (Figs 4d, 5f, arrows).

Cytoplasm colourless, containing some shining globules and food vacuoles with bacteria (possibly?). Contractile vacuole posterior to the rightmost transverse cirrus (Fig. 5d, arrow). Macronucleus slightly curved-bar-shaped (Fig. 4k). Locomotion typical of the genus.

Ciliary pattern rather stable, always 10 frontoventral and 5 transverse cirri (Fig. 4h, j); cirrus V/2 (Fig. 5g, arrowhead) very close to cirrus VI/2; cirrus II/1 almost at the same level as VI/1 (Fig. 5g, arrows). Two left marginal cirri (Fig. 4j, arrows) positioned posterior to the transverse cirri and close to two caudal cirri. Dorsal kineties number 6-7 (mostly 6), leftmost one of which is remarkably shortened at its anterior end, and consists of only 2-4 dikinetids; all kineties somewhat sparsely ciliated, middle dorsal kinety with about 8-11 dikinetids. Dorsal silverline system double-eurystomus type (Figs $4 \mathrm{~h}, \mathrm{i}$ and $5 \mathrm{~h}$ ).

Comparison and discussion. Until now, 9 small marine Euplotes with the double-eurystomus type dorsal silverline system have been reported. Six of these, Euplotes alatus Kahl, 1932, Euplotes balteatus (Dujardin, 1841) Kahl, 1932, Euplotes magnicirratus Kahl, 1932, Euplotes quinquecarinatus Gelei, 1950, Euplotes plicatum Valbonesi, 1997 and Euplotes trisulcatus Kahl, 1932, have 10 frontoventral and 2 marginal cirri, and thus can be compared with E. parabalteatus. However, these six species have conspicuous dorsal ridges which are absent in 


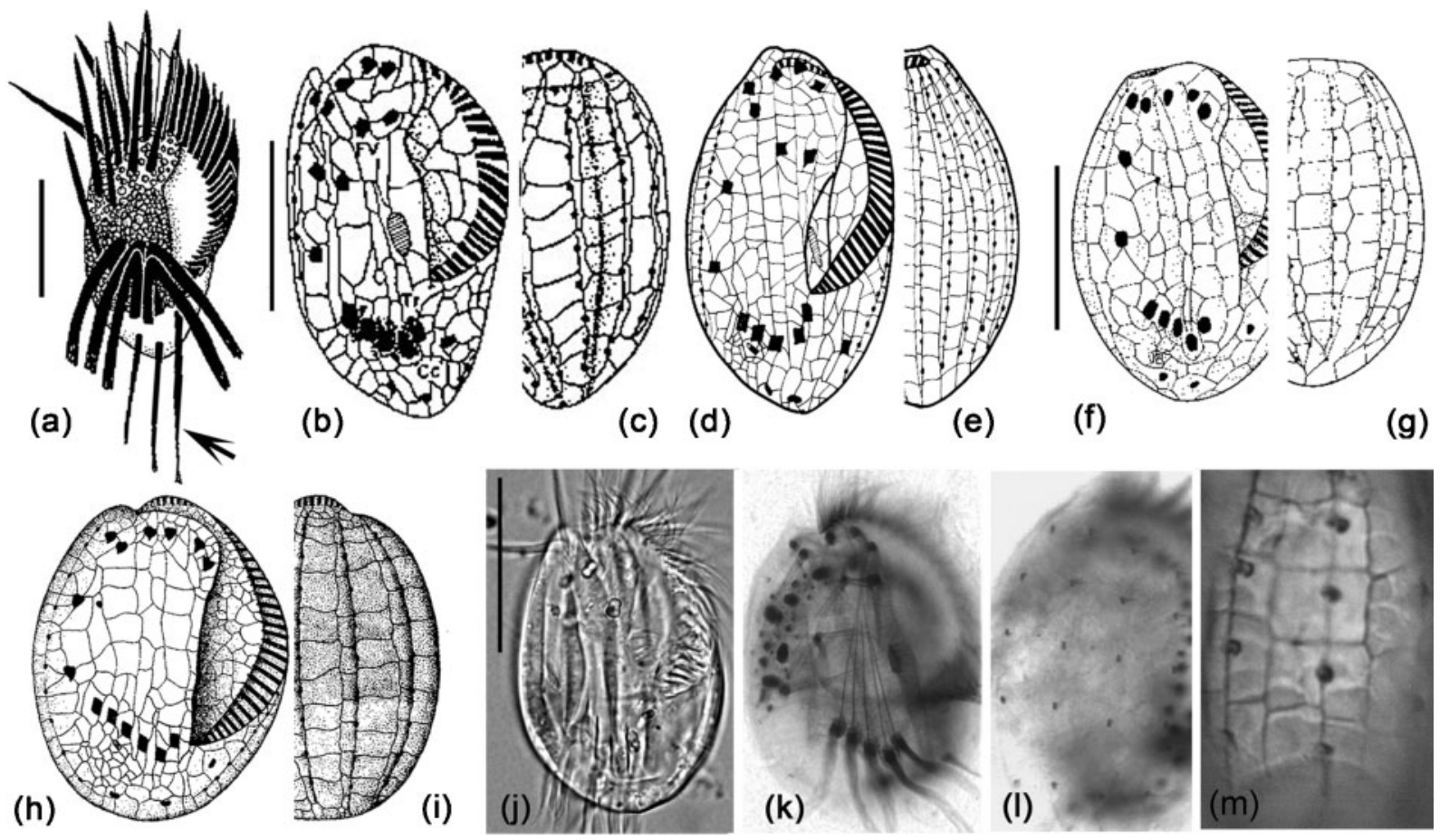

Fig. 3. Morphologically similar marine Euplotes species with double-patella silverline pattern and single marginal cirrus. (a-c) E. algivora Agatha, 1990 (Agatha et al., 1990; arrow marks the single long marginal cirrus); (d, e) E. zenkewitchi Burkovsky, 1970 (Burkovsky, 1970); (f, g) E. raikovi Agamaliev, 1966 (Washburn \& Borror, 1972); (h, i) E. strekovi Agamaliev, 1967 (Agamaliev, 1967); (j-m) E. rariseta Curds et al., 1974 (Ma et al., 2007). Bars, $30 \mu \mathrm{m}$ [a (also applies to d and e), b (also applies to $\mathrm{C}$ ), $\mathrm{f}$ (also applies to $\mathrm{g}-\mathrm{i}$ ) and $\mathrm{j}$ (also applies to $\mathrm{k}$ and $\mathrm{I})$ ].

E. parabalteatus. Posterior-located marginal cirri and cirrus $\mathrm{V} / 2$ of E. parabalteatus also distinguish this novel species from some of its congeners. Other differences used for further species separation are presented below.
According to Borror (1968), E. alatus has a relatively shorter adoral zone (half vs over two-thirds of cell length) and a C-shaped macronucleus (vs curved-bar-shaped) (Borror, 1968; Fig. 6a-c, Table 4).

Table 3. Comparison of six morphologically related marine Euplotes species with the double-patella dorsal silverline pattern and a single marginal cirrus

Species: 1, E. sinicus; 2, E. algivora; 3, E. zenkewitchi; 4, E. raikovi; 5, E. rariseta; 6, E. strekovi. NA, Not available.

\begin{tabular}{|c|c|c|c|c|c|c|}
\hline Characteristic & 1 & 2 & 3 & 4 & 5 & 6 \\
\hline Cell size in vivo $(\mu \mathrm{m})^{*}$ & $65-92 \times 37-62$ & $40-59 \times 24-40$ & $70-90 \times 45-55$ & $50-64 \times 40-56$ & $30-50 \times 20-40$ & $45-60 \times 38-40$ \\
\hline Adoral membranelles & $38-46$ & $28-37$ & $50-60$ & $22--30$ & $17-22$ & $33-38$ \\
\hline Frontoventral cirri & 10 & 10 & 9 & $8 \dagger$ & 10 & $9 \dagger$ \\
\hline Dorsal kineties & 7 & 6 & $8-10$ & $7-8$ & 7 & 6 \\
\hline $\begin{array}{l}\text { Dikinetids in mid-dorsal } \\
\text { kinety }\end{array}$ & $11-16$ & $7-12$ & $16-18$ & $10-13$ & $5-7$ & 10 \\
\hline Silverline system & Double-patella-I & Double-patella-I & Double-patella-II & Double-patella-I & Double-patella-I & Double-patella-II \\
\hline Other special features & $\begin{array}{c}\text { Dorsal side highly } \\
\text { ridged; fine } \\
\text { marginal cirrus }\end{array}$ & $\begin{array}{c}2 \text { Dorsal ridges; } \\
\text { marginal cirrus } \\
\text { conspicuously } \\
\text { long }\end{array}$ & NA & $\begin{array}{l}\text { Dorsal side slightly } \\
\text { ridged; single } \\
\text { reduced cirrus } \\
\text { present }\end{array}$ & $\begin{array}{l}\text { Dorsal side } \\
\text { slightly ridged }\end{array}$ & $\begin{array}{l}\text { Single reduced } \\
\text { cirrus }\end{array}$ \\
\hline Reference & Present work & Agatha et al. (1990) & Burkovsky (1970) & Jiang et al. (2008) & Ma et al. (2007) & Agamaliev (1967) \\
\hline
\end{tabular}

${ }^{\star}$ Based on impregnated specimens.

$\dagger$ Including the reduced cirrus. 

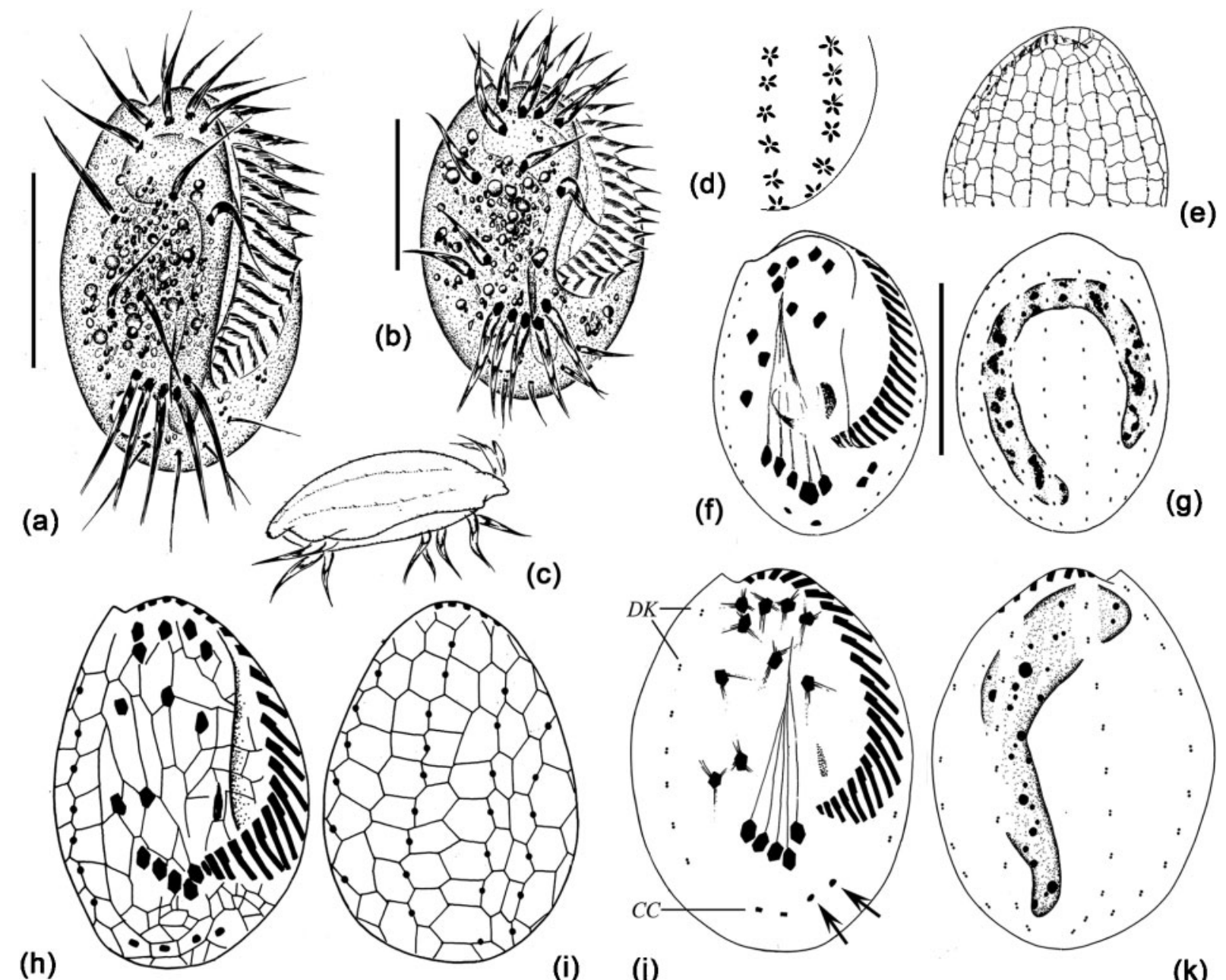

(c)

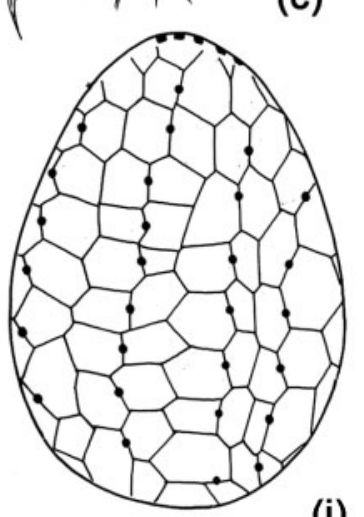

(i)

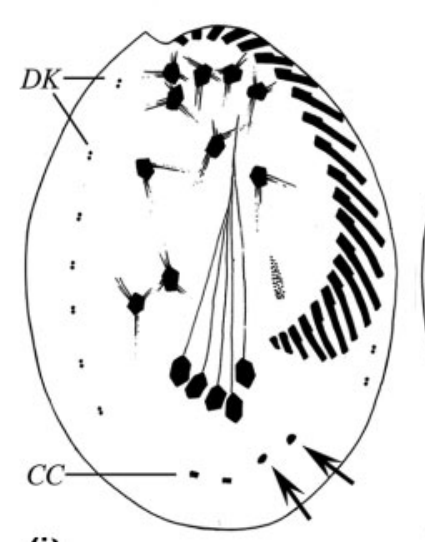

(j)

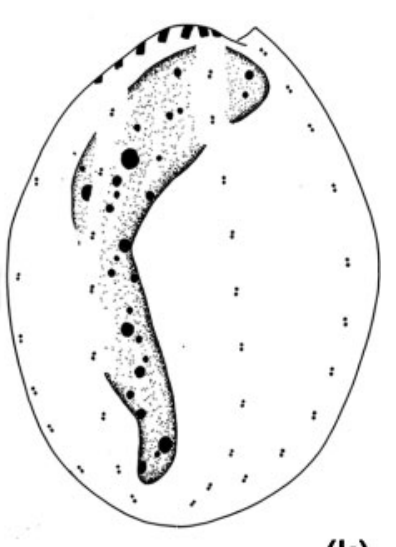

(k)

Fig. 4. E. parabalteatus sp. nov. in vivo $(\mathrm{a}-\mathrm{d})$, and after silver nitrate $(\mathrm{h}, \mathrm{i})$ and protargol $(\mathrm{j}, \mathrm{k})$ impregnation, and $E$. balteatus Kahl, 1932 (e-g) (Song \& Wilbert, 2002). (a) Ventral view of a representative specimen. (b) Ventral view of a plumper individual. (c) Lateral view. (d) Portion of dorsal view, showing the granules around dorsal cilia beneath the pellicle. (e) Portion of dorsal silverline system. ( $f, g)$ Infraciliature of the same individual on ventral $(f)$ and dorsal $(g)$ sides. ( $h$, i) Silverline system on ventral $(h$ ) and dorsal (i) sides. (j, k) Ventral and dorsal views, respectively, of the same specimen, showing infraciliature and nuclear apparatus. Arrows in (j) indicate the marginal cirri. CC, caudal cirri. DK, dorsal kineties. Bars, $20 \mu \mathrm{m}$ [a (also applies to h-k), b and $f$ (also applies to $g$ )].

E. quinquecarinatus was first briefly described by Gelei (1950). Borror (1968) identified a morphospecies as E. quinquecarinatus, and described the silverline system for the first time as 'extremely similar to E. charon', but when it came to the comparison, he mistook it as the patella-type. Curds (1975) accepted Borror's identification. Compared to E. parabalteatus, E. quinquecarinatus has more dorsal kineties (9 vs 6-7) and a C-shaped macronucleus (vs curved-bar-shaped) in addition to the differences mentioned above (Borror, 1968; Fig. 6d-f, Table 4).

E. magnicirratus differs from E. parabalteatus in its relatively strong cirri (vs normal cirri), more adoral membranelles (49-52 vs 19-23) and the inverted-C-shaped macronucleus (vs curved-bar-shaped) (Carter, 1972; Fig. $6 \mathrm{~g}-\mathrm{i}$, Table 4$)$.

E. plicatum can be clearly separated from E. parabalteatus by more dorsal kineties (10 vs $6-7)$ and the inverted-Cshaped macronucleus (vs curved-bar-shaped) (Valbonesi et al., 1997; Table 4).

E. trisulcatus resembles E. parabalteatus in cell size, infraciliature and macronucleus shape. However, three prominent furrows in E. trisulcatus were described by both Tuffrau (1960) and Carter (1972) (Fig. 6j-l, Table 4). In combination with difference in the position of cirrus V/2 as mentioned above, we suggest these should be treated as two distinct species. 

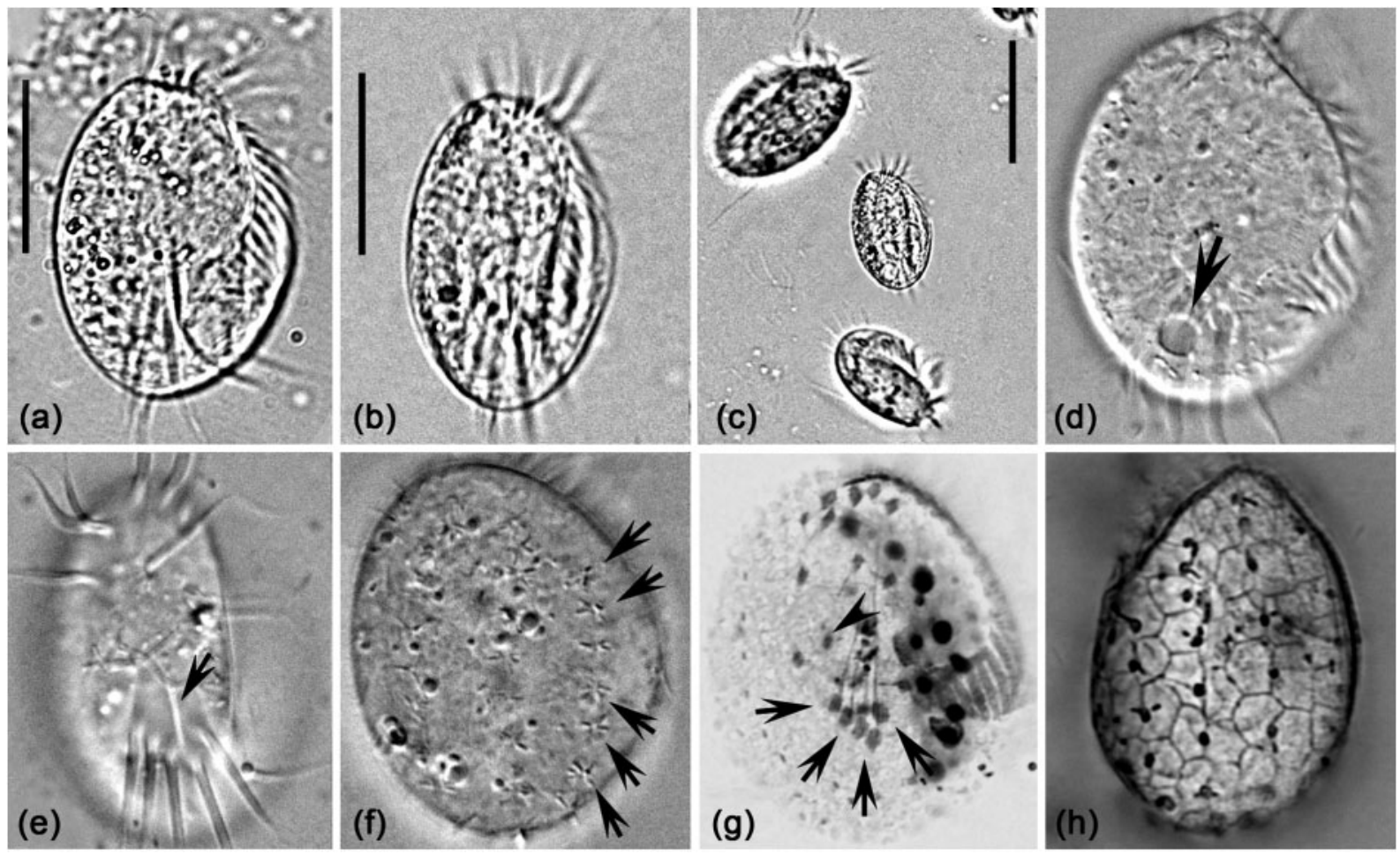

Fig. 5. Photomicrographs of E. parabalteatus sp. nov. in vivo (a-f), and after protargol (g) and silver nitrate (h) impregnation. $(a, b)$ Ventral views. (c) Differently sized and shaped cells. (d) Ventral view. Arrow points to the contractile vacuole. (e) Ventral view. Arrow shows the only short ridge between transverse cirri on ventral side. (f) Dorsal view. Arrows point to the granules around the dorsal cilia. (g) Ventral view of infraciliature. Arrowhead points to the posterior-located cirrus V/2; arrows indicate the closely arranged transverse cirri. (h) Dorsal view of silverline system. Bars, $20 \mu \mathrm{m}$ [a, also applies to d-h) and b] and $30 \mu \mathrm{m}$ (c).

Tuffrau (1959) described a high level of variability in cell size $(30-150 \mu \mathrm{m}$ long) and in the number of adoral membranelles (25-30 to 70-80) of E. balteatus, which depend upon its food source. This description by Tuffrau (1959) is a brief description without details of other characters (e.g. the number of dorsal kineties and dikinetids in the mid-dorsal kinety). Here, we can only compare E. parabalteatus morphometrically with the population of E. balteatus described by Song \& Wilbert (2002) (Fig. 4e-g, Table 4). Both are similar in cell shape and size, ciliary pattern and their silverline system; $E$. parabalteatus, however, can be separated from E. balteatus by having fewer dorsal kineties (6-7 vs 9) and a less curved macronucleus in addition to the differences mentioned above.

\section{Phylogenetic analyses of the two novel species and $E$. rariseta based on SSU rRNA gene sequences}

The phylogenetic trees constructed using three different methods (BI, ML and MP) showed identical topological structure, hence only one tree is presented here (Fig. 7).
The topologies are consistent with previous molecular analyses (Yi et al., 2009). As shown in Fig. 7, all Euplotes species form a well-supported group with high posterior probability and bootstrap values (BI $>0.95, \mathrm{ML}$ and MP >0.90). This group includes five well-supported clades and several species for which relationships remain unresolved. E. sinicus and E. parabalteatus fall within the family Euplotidae in all three trees (BI 1.00, ML and MP $100 \%)$ and both branch independently at the basal position as a sister group to all other Euplotes species. The SSU rRNA genes of the two morphologically closely related species, E. algivora and E. balteatus, have not been sequenced yet and therefore their genetic separation from their congeners remains unknown.

It is noteworthy that the new sequence of E. rariseta reported here did not cluster with the sequence (AF492706) obtained by our group in 2002 (Song et al., 2004). Our isolate of E. rariseta clusters strongly with another isolate of this species from Italy (AJ305248). Both sequences branch within the poorly resolved radiation of Euplotes, including two monophyletic clades represented by E. muscicola and E. magnicirratus, respectively. 


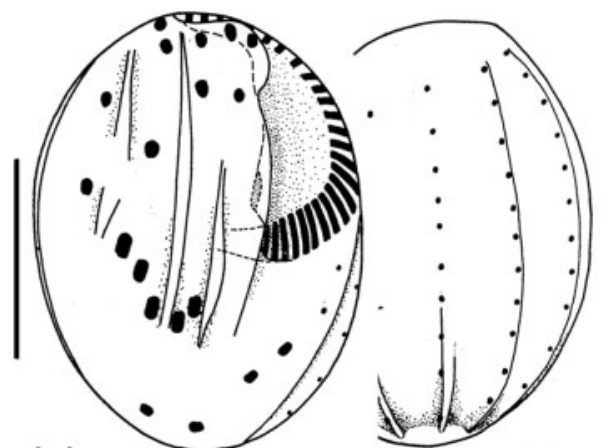

(a)

(b)

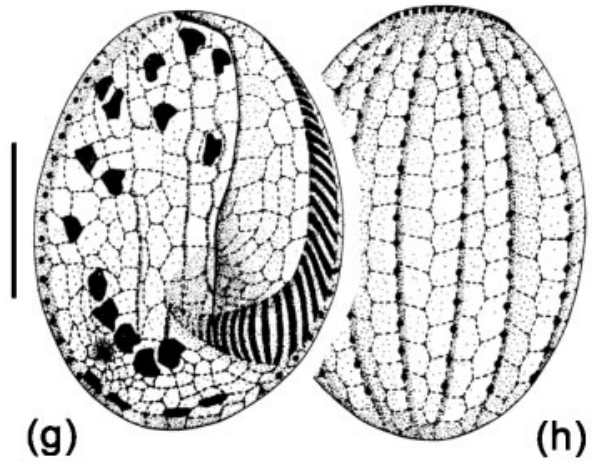

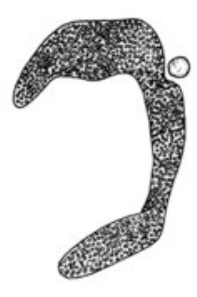

(c)

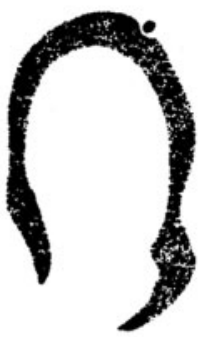

(i)

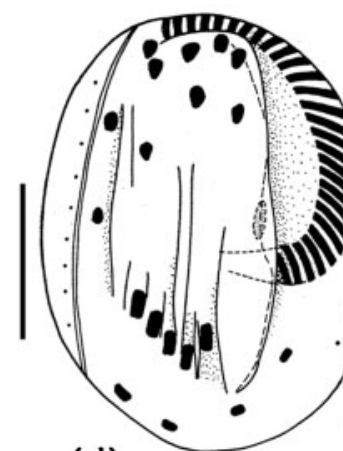

(d)

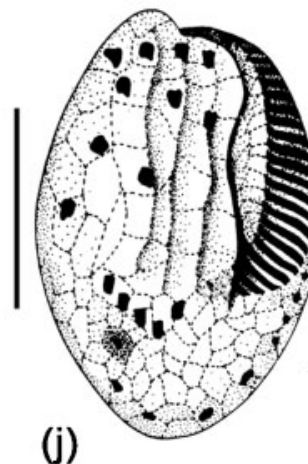

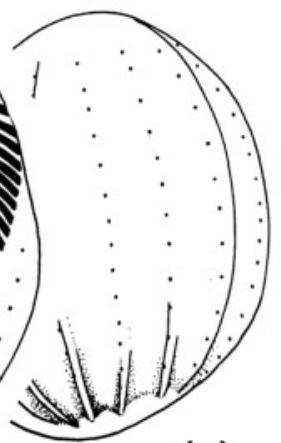

(e)

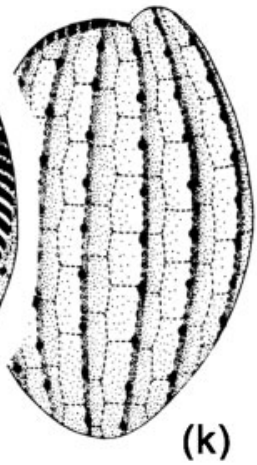

(k)

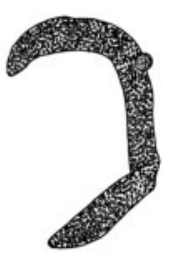

(f)

Fig. 6. Morphologically similar small marine Euplotes species with a double-eurystomus silverline pattern, and 10 frontoventral and 2 marginal cirri. (a-c) E. alatus Kahl, 1932 (Borror, 1968), (d-f) E. quinquecarinatus sensu Borror, 1968 (Borror, 1968), (g-i) E. magnicirratus Carter, 1972 (Carter, 1972), (j-l) E. trisulcatus Kahl, 1932 (Carter, 1972). Bars, $20 \mu \mathrm{m}$ [a (also applies to $\mathrm{b}$ and $\mathrm{c}$ ), $\mathrm{d}$ (also applies to e and f), g (also applies to $\mathrm{h}$ and $\mathrm{i}$ ) and $\mathrm{j}$ (also applies to $\mathrm{k}$ and $\mathrm{l})$ ].

However, the so-called E. rariseta isolate from Song et al., (2004) (AF492706) clusters with E. nobilii as a sister group to this radiation. By rechecking the slides deposited in our lab, we found that the isolate was misidentified. Unfortunately, however, the quality of the specimen is now too poor to allow for accurate identification, but it is clear that the cells are larger and have very obvious ridges on the ventral and dorsal sides, and thus cannot be $E$. rariseta (Song \& Packroff, 1997). It was treated as an unidentified Euplotes species in this analysis.

Table 4. Comparison of seven morphologically related small marine Euplotes species with the double-eurystomus dorsal silverline pattern, and 10 frontoventral and 2 marginal cirri

Species: 1, E. parabalteatus; 2, E. alatus; 3, E. quinquecarinatus; 4, E. magnicirratus; 5, E. plicatum; 6, E. trisulcatus; 7, E. balteatus.

\begin{tabular}{|c|c|c|c|c|c|c|c|}
\hline Characteristic & 1 & 2 & 3 & 4 & 5 & 6 & 7 \\
\hline Cell size in vivo $(\mu \mathrm{m})$ & $30-35$ & About 40 & About 60 & $54^{*}$ & $42-55$ & $35-50$ & $40-70$ \\
\hline Adoral membranelles & $19-23$ & About $30 \dagger$ & About $30 \dagger$ & $49-52$ & $22-25$ & $25-36$ & $27-33$ \\
\hline Dikinetids in mid-row & $8-11$ & About $10 \dagger$ & About $13 \dagger$ & $13-17$ & 14 & About 9? & $9-14$ \\
\hline Shape of macronucleus & $\begin{array}{c}\text { Curved-bar- } \\
\text { shaped }\end{array}$ & C-shaped & C-shaped & $\begin{array}{l}\text { Inverted } \\
\text { C-shaped }\end{array}$ & $\begin{array}{l}\text { Inverted } \\
\text { C-shaped }\end{array}$ & $\begin{array}{c}\text { Curved-bar- } \\
\text { shaped }\end{array}$ & $\begin{array}{c}\text { Inverted } \\
\text { C-shaped }\end{array}$ \\
\hline
\end{tabular}

*Probably from impregnated specimens.

$\dagger$ Counted from illustrations. 


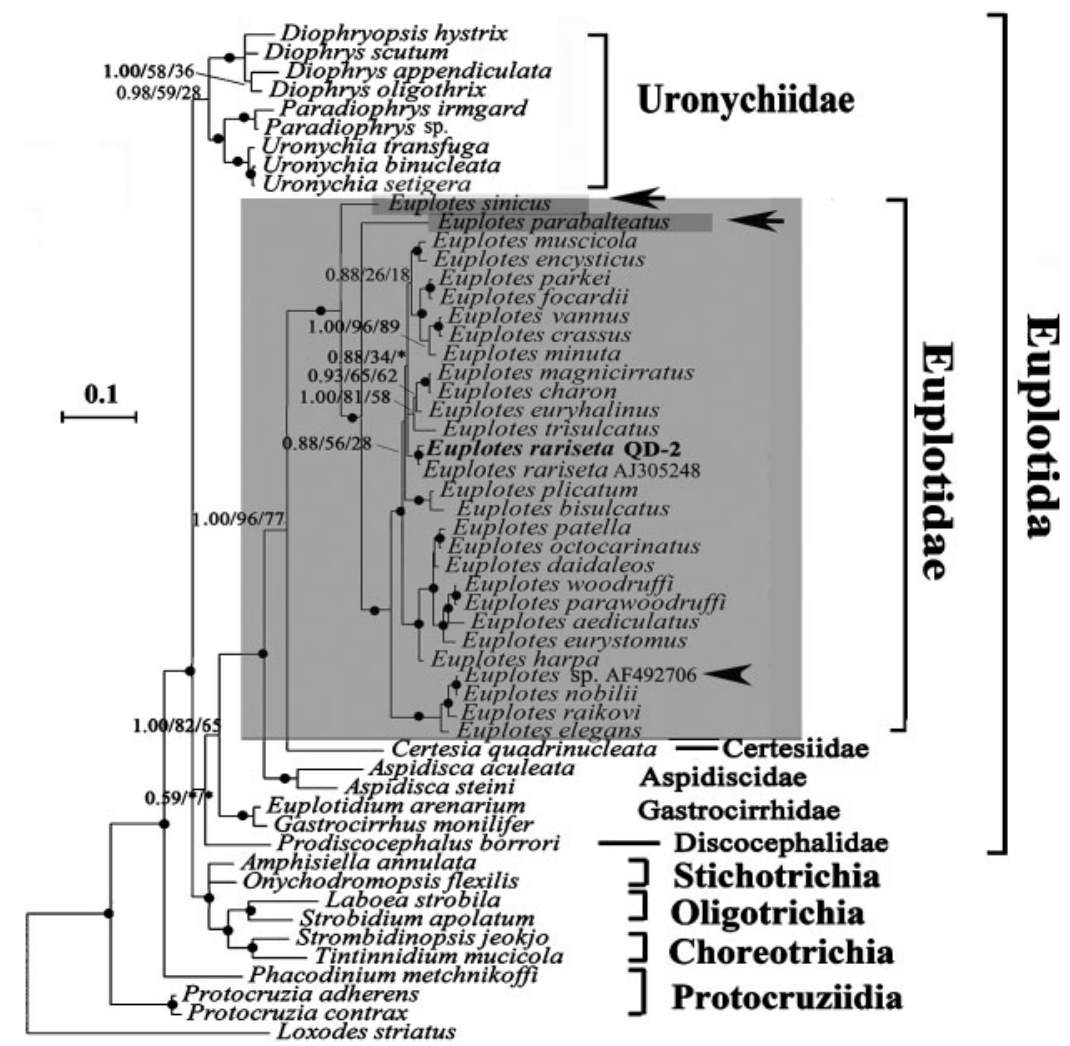

Fig. 7. Phylogenetic tree based on SSU rRNA gene sequences showing the position of $E$. sinicus, E. parabalteatus and E. rariseta by $\mathrm{BI}$, $\mathrm{ML}$ and MP. Numbers near branches are: BI posterior probability value/ML bootstrap value/ MP bootstrap value. An asterisk indicates disagreement among phylogenies. The wellsupported (>0.95 BI, >90\% ML, >90\% MP) branches are marked with solid circles. Family Euplotidae is highlighted in grey. The positions of $E$. sinicus and E. parabalteatus are denoted with arrows and highlighted in darker grey; the arrowhead refers to the previously misidentified $E$. rariseta. The scale bar corresponds to 10 substitutions per 100 nucleotide positions.

\section{ACKNOWLEDGEMENTS}

This work was supported by the Nature Science Foundation of China (project nos 40976075 and 30870264), the 111 Project (no. B08049) and a grant from the Center of Excellence in Biodiversity, King Saud University. Thanks are due to Dr Zhenzhen Yi, OUC, for kindly reading the draft and some helpful suggestions.

\section{REFERENCES}

Agamaliev, F. G. (1967). Faune des ciliés mésopsammiques de la côte ouest de la mer Caspienne. Cah Biol Mar 8, 359-402 (in French).

Agatha, N., Wilbert, M., Spindler, M. \& Elbrächter, M. (1990). Euplotide ciliates in sea ice of the Weddell Sea (Antarctica). Acta Protozool 29, 221-228.

Berger, H. (2006). Monograph of the Urostyloidea (Ciliophora, Hypotricha). Monogr Biol 85, 1-1303.

Borror, A. C. (1968). Systematics of Euplotes (Ciliophora, Hypotrichia); toward union of the old and the new. J Protozool 15, 802-808.

Borror, A. C. (1972). Revision of the order Hypotrichida (Ciliophora, Protozoa). J Protozool 19, 1-23.

Burkovsky, I. V. (1970). The ciliates of the mesopsammon of the Kandalaksha Gulf (White Sea). I. Acta Protozool 7, 475-489 (in Russian with English summary).

Carter, H. P. (1972). Infraciliature of eleven species of the genus Euplotes. Trans Am Microsc Soc 91, 466-492.

Curds, C. R. (1975). A guide to the species of the genus Euplotes (Hypotrichida, Ciliatea). Bull Br Mus (Nat Hist) Zool 28, 1-61.
Curds, C. R. (1977). Notes on the morphology and nomenclature of three members of the Euplotidae (Protozoa; Ciliatea). Bull Br Mus (Nat Hist) Zool 31, 267-278.

Elwood, H. J., Olsen, G. J. \& Sogin, M. L. (1985). The small-subunit ribosomal RNA gene sequences from the hypotrichous ciliates Oxytricha nova and Stylonychia pustulata. Mol Biol Evol 2, 399-410.

Gelei, J. (1950). Uj euplotesek a Tisza vizrenszeréböl XI. Közlemény a Magyar fauna csillósairól. Ann Biol Univ Szeged 1, 243-247 (in Hungarian).

Hu, X. (2008). Cortical structure in non-dividing and dividing Diophrys japanica spec. nov. (Ciliophora, Euplotida) with notes on morphological variation. Eur J Protistol 44, 115-129.

Jiang, J., Shao, C., Li, L., Ma, H., Gong, J. \& Song, W. (2008). Morphological studies on seven hypotrichous ciliates (Protozoa, Ciliophora) from coastal waters off Qingdao, China. Acta Zootaxon $\operatorname{Sin}$ 33, 115-119 (in Chinese with English summary).

Kumar, S., Tamura, K. \& Nei, M. (2004). MEGA3: integrated software for molecular evolutionary genetics analysis and sequence alignment. Brief Bioinform 5, 150-163.

Ma, H.-G., Jiang, J.-M., Hu, X.-Z., Shao, C. \& Song, W.-B. (2007). Morphology and morphogenesis of the marine ciliate, Euplotes rariseta (Ciliophora, Euplotida). Acta Hydrobiol Sin 32 (suppl), 57-62 (in Chinese with English summary).

Song, W. \& Packroff, G. (1997). Taxonomische Untersuchungen an marinen Ciliaten aus China mit Beschreibungen von zwei neuen Arten, Strombidium globosaneum nov. spec. und S. platum nov. spec. (Protozoa, Ciliophora). Arch Protistenkd 147, 331360 (in German).

Song, W. \& Wilbert, N. (1997). Morphological investigations on some free living ciliates (Protozoa, Ciliophora) from China Sea with 
description of a new hypotrichous genus, Hemigastrostyla nov. gen. Arch Protistenkd 148, 413-444.

Song, W., Wilbert, N., Chen, Z. \& Shi, X. (2004). Considerations on the systematic position of Uronychia and related euplotids based on the data of ontogeny and 18S rRNA gene sequence analyses, with morphogenetic redescription of Uronychia setigera Calkins, 1902 (Ciliophora, Euplotida). Acta Protozool 43, 313-328.

Song, W., Shao, C., Yi, Z., Li, L., Warren, A., Al-Rasheid, A. K. \& Yang, J. (2009). The morphology, morphogenesis and SSrRNA gene sequence of a new marine ciliate, Diophrys apoligothrix spec. nov. (Ciliophora; Euplotida). Eur J Protistol 45, 38-50.

Tuffrau, M. (1954). Les caractères specifiques dans le genre Euplotes (Note préliminaire). Bull Soc Zool Fr 15, 1-77.

Tuffrau, M. (1959). Polymorphisme par anisotomie chez le cilié Euplotes balteatus (Dujardin). C R Acad Sci Paris 248, 3055-3057.

Tuffrau, M. (1960). Révision du genre Euplotes, fondée sur la comparaison des structures superficielles. Hydrobiologia 15, 1-77.

Valbonesi, A., Apone, F. \& Luporini, P. (1997). Morphology and biology of a new species of Euplotes, Euplotes plicatum sp. n. (Ciliophora: Euplotidae). Acta Protozool 36, 287-294.

Washburn, E. S. \& Borror, A. C. (1972). Euplotes raikovi Agamaliev, 1966 (Ciliophora, Hypotrichida) from New Hampshire: description and morphogenesis. J Protozool 19, 604-608.
Wilbert, N. (1975). Eine verbesserte Technik der Protargolimprägnation für Ciliaten. Mikrokosmos 64, 171-179.

Wilbert, N. \& Song, W. (2008). A further study on littoral ciliates (Protozoa, Ciliophora) near King George Island, Antarctica, with description of a new genus and seven new species. J Nat Hist 42, 9791012.

Yi, Z., Song, W., Warren, A., Roberts, D., Al-Rasheid, K. A. S., Chen, Z., Al-Farraj, S. A. \& Hu, X. (2008a). A molecular phylogenetic investigation of Pseudoamphisiella and Parabirojimia (Protozoa, Ciliophora, Spirotrichea), two genera with ambiguous systematic positions. Eur J Protistol 44, 45-53.

Yi, Z., Song, W., Shao, C., Warren, A., Al-Rasheid, K. A. S., Roberts, D., Miao, M., Al-Quraisy, S. A. \& Chen, Z. (2008b). Phylogeny of some systematically uncertain urostyloids - Apokeronopsis, Metaurostylopsis, Thigmokeronopsis (Ciliophora, Stichotrichia) estimated with small subunit rRNA gene sequence information: discrepancies and agreements with morphological data. Eur J Protistol 44, 254262.

Yi, Z., Song, W., Clamp, J., Chen, Z., Gao, S. \& Zhang, Q. (2009). Reconsideration of systematic relationships within the order Euplotida (Protista, Ciliophora) using new sequences of the gene coding for small-subunit rRNA and testing the use of combined data sets to construct phylogenies of the Diophrys-complex. Mol Phylogenet Evol 50, 599-607. 